\title{
Mediation in Marriage Disputes and Divorce (Analytical Study on the Application of Mediation in the Gorontalo Religious Court)
}

\author{
Yasin \\ Institut Agama Islam Negeri Manado \\ Email: yasin.yetta@iain-manado.ac.id \\ Faradila Hasan \\ Institut Agama Islam Negeri Manado \\ Email: faradila.hasan@iain-manado.ac.id \\ Fikri Amiruddin \\ Institut Agama Islam Negeri Manado \\ Email: fikri.amiruddin@gmail.com
}

\begin{abstract}
This article discussed mediation as a way of resolving marital disputes. Divorce was one form of marital dispute in the Religious Courts, and in terms of resolving marital disputes, mediation was required. Although the rules of mediation in the judiciary are very clear, the facts show that the disputing parties and the courts have not optimized their use so that the divorce rate every year does not experience a significant decrease; on the contrary, it increases. The theory regarding mediation procedures in the Religious Courts has clearly been stated in the Supreme Court of the Republic of Indonesia (No. 1 of 2016). This article aims to analyze the implementation of the mediation process at the Gorontalo Religious Court. Therefore, it is necessary to conduct more in-depth research on the effectiveness of the Gorontalo Religious Court to resolve marital disputes that lead to divorce, which can be avoided, and the litigants can get back together and foster a 'sakinah mawaddah wa rahmah' household. This article used a qualitative with an empirical juridical approach. It could be concluded that the mediation had been carried out at the Gorontalo Religious Court under the Regulation of the Supreme Court of the Republic of Indonesia (No. 1 of 2016). Four factors affect successful and unsuccessful mediation, namely the litigation party factor, the mediator factor, the advocate or lawyer factor, and the representative mediation room factor.
\end{abstract}

Keywords: mediation, marital disputes, Gorontalo religious court

\begin{abstract}
Abstrak: Artikel ini membahas mengenai mediasi sebagai salah satu cara penyelesaian sengketa perkawinan. Perceraian merupakan salah satu bentuk sengketa perkawinan di Pengadilan Agama dan dalam hal penyelesiaian sengketa perkawinan tersebut maka diperlukan mediasi. Meski aturan mediasi di peradilan sangat jelas, namun fakta menunjukkan bahwa para pihak yang bersengketa dan pengadilan belum mengoptimalkan penggunaannya, sehingga angka perceraian setiap tahun tidak mengalami penurunan yang siknifikan, bahkan sebaliknya meningkat. Teori mengenai prosedur mediasi di Pengadilan Agama secara jelas telah dituangkan Peraturan Mahkamah Agung Republik Indonesia (No. 1 Tahun 2016). Tujuan dari artikel ini adalah
\end{abstract}


untuk menganalisis implementasi proses mediasi di Pengadialan Agama Gorontalo. Oleh karena itu, perlu dilakukan penelitian yang lebih mendalam mengenai Efektifitas Pengadilan Agama Gorontalo dalam upaya penyelesaian sengketa perkara perkawinan yang bermuara pada perceraian dapat dihindari, dan para pihak yang berperkara dapat rukun kembali dan membina rumah tangga yang 'sakinah mawaddah wa rahmah'. Artikel ini menggunakan metode kualitatif dengan pendekatan yuridis empiris. Dapat disimpulkan bahwa mediasi telah dilakukan di Pengadilan Agama Gorontalo sudah sesuai dengan Peraturan Mahkamah Agung Republik Indonesia (No. 1 Tahun 2016). Faktor mediasi berhasil dan tidak berhasil dapat disebabkan oleh 4 (empat) faktor yaitu faktor pihak berperkara, faktor mediator dan faktor advokat atau pengacara dan faktor ruang mediasi yang representatif.

Kata-kata kunci: mediasi, sengketa perkawinan, pengadilan agama Gorontalo

\section{Introduction}

Marriage is a legal concept (legal conceptual) where the act gives rise to many rights and obligations between the parties who agree (husband and wife). Their legal marriage contract leads to the existence of rights and obligations between husband and wife. It is a source of their legal contract as long as they maintain their binding contract, and the termination of the marriage contract lasts to the end of their rights and obligations between husband and wife in a household. Therefore, the existence of the legal marriage contract becomes very important as the basic foundation in building a household.

The marriage agreement is based on a free strong will and desire of both a groom-to-be and a bride-to-be to express their agreement in the form of a contract. They are free to express their will, and there is no coercion from others to make a marriage contract. The marriage contract does not only support humans' external and internal needs but also maintains human existence as dignified creatures through legal lineages. Husband and wife's rights and obligations in marriage are mutual, where the husband's obligations are the rights of the wife, and the wife's obligations are the rights of the husband. This mutual nature applies to obligations towards their children. Therefore, the obligations and rights of husband and wife in marriage are the fundamental elements to support a household 1 .

Fulfillment of the rights and obligations between a husband and a wife in a fair and 'makruf' will be able to realize a 'sakinah' household, 'mawaddah wa rahmah'. Mahmoud Hoballah stated that the main cause of household discomfort was due to the inexistent fulfillment of the rights and obligations of a husband and a wife in a fair and 'makruf', both material rights and obligations and immaterial rights and obligations. However, Mahmoud Hoballah also noted that the emotional maturity of a husband and a wife also affects their comfort, harmony, and peace in the household. These two things, according to Mahmoud Hoballah, are the main factor

${ }^{1}$ See, Ahmad Ibrahim Bik and Wasil'Alauddin Ahmad Ibrahim, Ahkam Ahwal al-Syakhsiyah fi Syari'at al-Islam wa al-Qanun, (Beirut: Dar Fikr al-Araby, 1997), pp. 715-727. As described in Syahrizal Abbas's book, Mediasi: Dalam Perspektif Hukum Syariah, Hukum Adat dan Hukum Nasional, Ed. I, (Jakarta: Kencana, 2009), p. 179. 
causing disputes or disputes that lead to a divorce ${ }^{2}$. In community practice, a dispute can still be resolved through family deliberation involving elements of village elders, community leaders, religious leaders (ulama/muballigh), or fellow families, or sometimes waiting for a special celebration 'Eid al-Fitr', which has become a Muslim tradition as a holy day for forgiveness. However, the dispute can no longer be resolved kinshiply, socially, or religiously. In that case, the dispute will automatically change, which will eventually escalate into a "dispute," and in the end, for its settlement, it must be submitted to the court as a "case."

Islam expects a marriage contract with a sacred value can be maintained forever (permanently) by husband and wife. However, Islam also understands the reality of husband and wife sometimes experience prolonged disputes and squabbles. These experiences culminate, make disharmonious households, and will bring harm. Therefore, Islam offers a solution called a divorce. As the solution, it is the last option for a household that can no longer be maintained. Disputes between husband and wife do not become the reason for severing marital relations but contain a process of mediation and reconciliation to maintain the household.

In the past, most divorces occurred because of a husband's will. The husband in the family is much stronger than the wife. The wife is more dependent on her husband materially and psychologically. When a divorce occurs, the wife and children feel more impacted ${ }^{3}$.

The impact of divorce is not only felt by husband and wife, but also their children, even broadly it will have an impact on the extended family of both parties, besides that it will have an impact on the loss of rights and responsibilities of husband and wife and also has something to do with it. With the psychological burden of both husband and wife and their children, the alternative as a last resort for divorce must be done through a legal process. However, previously mediation must be carried out to reconcile the conflict through the families.

A divorce is a form of marital dispute in Religious Courts. The Regulation of the Supreme Court of the Republic of Indonesia Number 1 of 2016 states that mediation is a method of peaceful dispute resolution that is appropriate, effective, and can open wider access for husband and wife to obtain a satisfactory and fair settlement ${ }^{4}$. Mediation is a problem-solving negotiation process, in which the impartial parties work together with the disputing parties to seek mutual agreement. The outside party is called a mediator, but the mediator does not have the authority to decide the dispute, the mediator only helps the parties resolve the issues authorized to him or her5.

The word 'mediation' means involving a third party as an advisor in resolving such a dispute. The meaning of mediation involves 3 (three) important elements. First, mediation is a process to resolve disputes that occur between two or more parties. Second, the parties involved in dispute resolution are outside the disputing parties. Third, the parties involved in the dispute resolution act as advisors and do not have any authority in making decisions. The etymological understanding of mediation comes from the Latin "mediare" which means being in the middle.

\footnotetext{
${ }^{2}$ See, Mahmoud Hoballah, "Marriage, Divorce and Inheritance in Islamic law". Dalam Hisham M. Ramadhan (ed), Understanding Islamic Law From Classical to Contemporary, (Newyork: Altamira Press, 2006), p. 113. As described in Syahrizal Abbas's book, ibid., p. 180.

${ }^{3}$ Gunawan, E., \& Hasan, F. Divorce Lawsuit Due to Polygamy in the Manado Religious Court. Al-Mizan, Vol.13, No.2, 2017, pp. 272-293.

${ }^{4}$ See, Regulation of the Supreme Court of the Republic of Indonesia Number 1 of 2016 concerning Mediation Procedures in Court.

${ }^{5}$ Khotibul Umam, Penyelesaian Sengketa di Luar Pengadilan, (Yogyakarta: Pustaka Yustisia, 2010), p. 10.
} 
This understanding refers to the role displayed by a third party, namely as a mediator in carrying out their duties to mediate and resolve disputes between the parties. 'Being in the middle means that the mediator must be neutral and impartial in resolving the dispute. He must be able to preserve the parties' interests fairly and equally to foster trust from the disputing parties ${ }^{6}$.

The etymological understanding of mediation is clear and emphasizes the existence of a third party as a mediator between the two disputing parties and only explains the nature of how mediation is, without explaining mediation in depth. This third party (the mediator) bridges the parties to resolve the dispute. So it is very clear that this understanding provides a difference between mediation and alternative dispute resolution. This third party has a neutral nature between the two disputing parties and provides or finds an agreement to satisfy the parties.

Meanwhile, the explanation of mediation in terminology is based on the understanding of mediation according to the parties, namely to assist the parties, either individually or collectively, to identify the problems in dispute and develop proposals or methods to resolve the disputes being handled. Unlike the arbitrator, the mediator does not have the authority to decide every dispute, but the mediator can attend secret meetings and special discussions with the conflicting parties ${ }^{7}$.

Mediation is often equated with the meaning of arbitration. Meanwhile, the meaning of arbitration is another form of dispute resolution using a third party (as opposed to the litigation process and jury assessment). In arbitration, the arbitrator listens to the facts presented by each party and then makes a decision as to who is responsible for the losses suffered by a plaintiff and how much a defendant must be responsible for paying the damages to the plaintiff. Subekti stated that arbitration is the settlement or termination of a dispute by a judge or judges based on the agreement that the parties will submit to or obey the decision given by the judge they choose ${ }^{8}$.

With the issuance of PERMA Number 1 of 2016 concerning mediation procedures in court, the mediation process in court where a lawsuit is a must and compulsory in every case. The consequences of a case are presented by both parties at the trial and the proceedings mediation is not taken or the case is directly examined and decided by the judge, then the legal consequences of the decision will be null and void because it is a violation of the provisions in Article 130 HIR/154 R.Bg "if, on the day of the trial that has been determined both parties to the litigation are present During the trial, the Chairperson of the Panel of Judges tries to reconcile the litigating parties. If peace can be reached, then an amicable decision will also be made on the day of the trial, and both parties are punished for complying with the agreed agreement" The application of mediation in the judiciary has been reconstructed from Article $130 \mathrm{HIR} /$ Article $154 \mathrm{RBg}$, known as the peaceful effort. In addition, it is also regulated in Article 39 of Law Number 1 of 1974, Article 65 of Law Number 3 of 2006, Articles 115, 131 (2), 143 (1-2), 144 of the Compilation of Islamic Law, and Article 32 PP No. 9 of 1975 and the mediation regulations were rearranged through PERMA Number 1 of 2016 concerning mediation procedures in courts.

6Ibid., p. 2.

${ }^{7}$ Rachmadi Usman, Pilihan Penyelesaian Sengketa Diluar Pengadilan, (Bandung: Citra Aditya Bakti, 2003), p. 240.

${ }^{8}$ Subekti, Arbitrase Perdagangan, (Bandung: Bina Cipta, 1992), p. 1 
The mediation process has been carried out under the provisions of PERMA No.1 of 2016. However, there are many obstacles and the efforts to reduce the divorce rate due to marital disputes have not undergone significant changes ${ }^{9}$.

Although the rules regarding mediation in the judiciary are very clear, the facts show that the parties to the dispute and the courts have not optimized the utilization so that the divorce rate every year is not decreasing. However, it is increasing, so that more in-depth studies and research are needed on the effectiveness of the application of mediation in resolving marital disputes at the Gorontalo Religious Court so that the settlement of marital disputes that lead to divorce can be avoided. The litigants can get back together and build a "sakinah mawaddah wa rahmah" household. This article is to analyze the implementation of the mediation process at the Gorontalo Religious Court.

The method of this study is qualitative using an empirical juridical approach. The research was conducted during 2020 at the Gorontalo City Religious Court. The data obtained from the Gorontalo Religious Court is data on mediation in marital disputes in 2019 and 2020. the author interviewed three mediator judges at the Gorontalo Religious Court, namely Drs. Syafrudin Mohammad, MH, Dra. Hj. Hasnia $\mathrm{HD}, \mathrm{MH}$, and Drs. Burhanudin Mokodompit to find out the factors causing the success or failure of Mediation at the Gorontalo Religious Court.

\section{Mediation in Court}

In the framework of reforming the bureaucracy of the Supreme Court of the Republic of Indonesia, which is oriented towards the vision of "the realization of a great Indonesian judiciary," one of the supporting elements is mediation as an instrument to increase public access to justice as well as the implementation of the principle of administering justice which is simple, fast and low cost as intended in article 2 paragraph 4, Law Number 49 of 2009 concerning judicial power.

Mediation, according to the Regulations of the Supreme Court, is the process of resolving the dispute in court through negotiations between the litigants, assisted by a mediator who has the position and function as a third-party neutral and impartial (impartiality) and as an assistant or helper to look into the possibility or an alternative dispute resolution that is best and mutually beneficial to the parties 10 .

In the application of mediation in the Religious Courts, if the parties are present at the court, the panel of judges will provide an opportunity for the parties to mediate. In Perma, Number 1 of 2016 provides a legal threat by stating that they do not have good faith if the litigants do not carry out mediation. Several conditions will cause the litigants or their proxies to be declared not in good faith, as stated in Article 7 paragraph (2).

Judges are required to follow the procedure for resolving disputes through mediation. In this case, the judges in their legal considerations are obliged to mention that efforts have been made to reconcile through mediation with its mediator's name. If the judge ignores the stages of the mediation process in examining the case, the judge can be subject to sanctions for violating the judge's code of ethics; if the case reaches the level of legal action, the high court judges,

${ }^{9}$ Hasan, F., Yusuf, N., \& Luntajo, M. M. R. The Adjudication of Marriage Disputes through Mediation at the Manado Religious Court. INNOVATIO: Journal for Religious Innovation Studies, Vol. 20, No. 2, 2020, pp. 97-110

${ }^{10}$ M. Hatta Ali, Peradilan Sederhana, Cepat dan Biaya Ringan Menuju Keadilan Restoratif, Ed. 1, (Bandung: Alumni, 2012), p. 361. 
before deciding the case, he or she decided to submit a mediation examination. The results then are sent back to the appellate court to decide the case ${ }^{11}$.

The provisions regarding the mediation procedure in Perma Number 1 of 2016 apply in litigation processes in court, both within the General Court and Religious Courts. Mediation is carried out by certified mediators, both judges, and non-judges. If there is no certified mediator in a court, an existing judge can be appointed. The litigants will be offered the choice of a mediator whom the assembly chairman will then appoint as a mediator in the case being examined ${ }^{12}$.

\section{Divorce and Mediation results at the Gorontalo Religious Court}

In its application in Indonesia, mediation is mandatory. It applies to civil disputes that are submitted to the court as mandated by Supreme Court Regulation (PERMA) Number 1 of 2016 concerning Mediation Procedures in Courts, then based on dictum letter (d) states that "mediation procedures in court, being part of civil procedural law can strengthen and optimize the function of the judiciary in dispute resolution ${ }^{13}$. Based on the dictum, the Chief Justice of the Supreme Court of the Republic of Indonesia issued a Decree of the Chief Justice of the Supreme Court of the Republic of Indonesia Number 108/KMA/SK/VI/2016 regarding the management of mediation in court. The application of the mediation procedure is required by referring to Article 130 of the 'HIR' and Article 154 of the RBg, which states that judges are required first to seek a peace process. Thus, mandatory mediation concerning the civil court process in Indonesia has a clear legal basis, so it will not cause problems from the legal aspect.

The Gorontalo Religious Court, as one of the implementing institutions of judicial power, examines, decides, and resolves cases at the first level between people who are Muslim in the fields of (a) marriage; (b) inheritance; (c) will; (d) grants; (e) 'waqf'; (f) 'zakat'; (g) 'infaq' (h) 'shadaqah', and (i) sharia economics as mandated by Article 49 of Law Number 3 of 2006 concerning Amendments to Law Number 7 of 1989 concerning the Religious Courts ${ }^{14}$ and all lawsuits (contentious) which is the authority of the Religious Courts, including cases that must go through a mediation process, and divorce cases as one type of case including in the field of marriage which dominates the number of cases received at the Gorontalo Religious Court every year.

Based on data obtained from the Junior Registrar of Laws, throughout 2019, the Gorontalo Religious Court handled 1,276 cases, with special details for divorce cases filed by the wife as many as 613 or $48.04 \%$, while divorce cases submitted by husbands were 199 cases or 15.59 \%. The divorce cases between 2019 were 812

${ }^{11}$ Amran Suadi, Pembaruan Hukum Acara Perdata di Indonesia: Menakar Beracara di Pengadilan Agama Secara Elektronik, Ed. I, (Jakarta: Kencana, 2019), p. 83. See, article 3 'Perma' No. 1, 2016 concerning Mediation Procedure in Court.

${ }^{12}$ Aco Nur and Amam Fakhur, Hukum Acara Elektronik di Pengadilan Agama, Ed. I, (Sidoarjo: Nizamia Learning Center, 2019), p. 61.

${ }^{13}$ See, Diktum point (d) Perma No. 1 2016, concerning Mediation Procedure in Court.

${ }^{14}$ See, article 49 laws (UU) No 32006 the changing of laws (UU) No 71989 concerning Religious Court. 
cases or $63.63 \%$ and divorce cases that were decided were "accepted" in 2019 as many as 667 cases or $85.40 \%$.

Furthermore, since 2020, the Gorontalo Religious Court handled 1,046 cases with special details on divorce cases submitted by the wife as many as 518 or $49.52 \%$ which were accepted, while divorce cases submitted by the husband were 168 cases or $16.06 \%$. Divorce cases in 2020 are 686 cases or $65.58 \%$ as a whole. Furthermore, the number of divorce cases, both sued and divorced divorces which were decided "accepted" in 2020 , was 578 cases or $84.25 \%$. For details, see the table below:

Table 1. Data on Divorce Cases at the Gorontalo Religious Courtat Gorontalo Religious Courts in 2019 and $2020^{15}$.

\begin{tabular}{|c|c|c|c|c|c|c|c|c|}
\hline \multirow[b]{2}{*}{ No } & \multirow[b]{2}{*}{ Year } & \multirow{2}{*}{$\begin{array}{c}\text { Number } \\
\text { of } \\
\text { Processed } \\
\text { cases }\end{array}$} & \multicolumn{2}{|c|}{$\begin{array}{c}\text { Type of accepted } \\
\text { cases }\end{array}$} & \multirow[b]{2}{*}{ Total } & \multirow{2}{*}{ Percentage } & \multirow{2}{*}{$\begin{array}{l}\text { Accepted } \\
\text { decisions }\end{array}$} & \multirow[b]{2}{*}{ Percentage } \\
\hline & & & $\begin{array}{c}\text { Sued } \\
\text { divorces }\end{array}$ & $\begin{array}{l}\text { Divorced } \\
\text { divorces }\end{array}$ & & & & \\
\hline 1. & 2019 & 1.276 & 613 & 199 & 812 & $63.63 \%$ & 667 & $85.40 \%$ \\
\hline 2. & 2020 & 1.046 & 518 & 168 & 686 & $63.47 \%$ & 578 & $84.25 \%$ \\
\hline
\end{tabular}

From the data in table 1 above ranged from 2019 to 2020, the number of divorce cases has decreased by 1.15\%. During 2019 and 2020, divorce cases have occurred in Gorontalo City, Gorontalo Province of 1,245 divorce cases.

Referring to the description above, the divorce rate increases every year, which divorces as a "main case" dominate types of cases in Religious Courts, especially in the Gorontalo Religious Court. The Indonesian Supreme Court has regulated some steps and various breakthroughs to reduce cases that enter the religious courts, including marital disputes through mediation efforts. This step is regulated in Supreme Court Regulation Number 1 of 2016 concerning Mediation Procedures in Courts Article 1 point 1 states that "mediation is a dispute resolution event through a negotiation process to obtain an agreement between the parties with the assistance of a mediator" 16 .

From the understanding of the Regulation of the Supreme Court (Perma), Number 1 of 2016, the main basis of the mediation process is the role of the disputing parties, which is based on good faith and volunteerism in the mediation process and a dispute resolution can be achieved as the result of the agreement of both parties.

Based on the divorce data at the Gorontalo Religious Court in 2019 and 2020 above, there is also a failure and success rate of mediation at the Gorontalo Religious Court based on mediation statistics in 2019 there are 155 cases, with the number of successful mediation as many as 11 cases or $7.09 \%$, unsuccessful mediation were 131 cases or $84.51 \%$, and mediation that could not be carried out with 6 cases or $3.87 \%$. In 2020, 143 cases were mediated, with 10 cases of successful mediation or $6.99 \%$, unsuccessful mediation of 129 cases or $90.20 \%$, and mediation that could not be carried out as many as 4 cases or $2.79 \%$. For details can be seen in Table 2 below:

Table 2. Statistical data of successful and failed mediations and mediation cannot be carried out at the Gorontalo Religious Court in 2019 and $2020^{17}$.

15Data source: 'Panitera Muda Hukum PA' Gorontalo in 2021, on 18 th of March 2021.

${ }^{16}$ See, article 1, No. 1 'Perma' No. 1, 2016 concerning Mediation Procedures in Court.

${ }^{17}$ Data source: 'Panitera Muda Hukum PA' Gorontalo in 2021, on $18^{\text {th }}$ of March 2021. 


\begin{tabular}{|c|c|c|c|c|c|c|c|c|}
\hline \multirow{2}{*}{$\begin{array}{c}\mathrm{N} \\
\mathrm{o}\end{array}$} & \multirow{2}{*}{ Year } & \multirow{2}{*}{$\begin{array}{c}\text { Mediated } \\
\text { cases }\end{array}$} & $\begin{array}{c}\text { Successfully } \\
\text { mediated }\end{array}$ & Percentage & $\begin{array}{c}\text { Unsuccessfully } \\
\text { mediated }\end{array}$ & Percentage & $\begin{array}{c}\text { Unimplemented } \\
\text { mediation }\end{array}$ & Percentage \\
\hline 1 & 2019 & 155 & 11 & $7.09 \%$ & 131 & $84.51 \%$ & 6 & $3.87 \%$ \\
\hline 2 & 2020 & 143 & 10 & $6.99 \%$ & 129 & $90.20 \%$ & 4 & $2.79 \%$ \\
\hline
\end{tabular}

The data shows that efforts to implement mediation at the Gorontalo Religious Court did not show the level of success as expected. The success of mediation has not reached half of the cases mediated, the description of the unsuccessful implementation of this mediation can occur because the litigants have been preceded by long negotiations between the families of the two parties, but did not reach an agreement so that the parties preferred the litigation route through the courts rather than resolving their cases through a mediator and the high failure of cases mediated at the Gorontalo Religious Court could occur because the Defendants/Defendants did not present in the first trial, especially in divorce cases so that the decision given by the judge is the 'verstek' decision. In addition, according to Drs. Syafrudin Mohammad, MH, and Dra. Hj. Hasnia HD, MH and Drs. Burhanudin Mokodompit stated that when mediation, the parties did not want to make peace, but during the next passage of time and the schedule for the next trial to be held, the parties usually withdrew their case in the courtroom in peace. However, the mediator's report did not succeed in reaching an agreement. It should be when they reconciled in the courtroom even though they did not make peace when in mediation. It could be categorized as successful in mediation ${ }^{18}$.

Referring to the information provided by the Junior Registrar of Laws at the Gorontalo Religious Court, if the divorce cases received in 2019 by the Gorontalo Religious Court were 812 cases, the cases decided by Verstek reached 657 cases or $80.91 \%$ cases. Divorce cases received in 2020 with 686 cases, the cases decided by Verstek reached 543 or 79.15 cases $^{19}$.

From this data, it is clear that cases that could be mediated in 2019 amounted to 155 cases, or $19.08 \%$ of which both parties were present and ready to participate in mediation. Likewise, in 2020, only 143 cases or $20.84 \%$ of cases could be mediated, and both parties were present and ready to participate in mediation. The success of mediation in the Religious Courts in 2019 and 2020, a case perspective, the Defendant/Respondent parties present in court are still low, only $7.09 \%$ and $6.99 \%$ success rates. The failure of mediation in 2019 and 2020, viewed from the perspective of the case, the parties (Defendant/Respondent) present at the trial court, was still high at $84.51 \%$ in 2019 and $90.20 \%$ in 2020 .

In the environment of the Religious Courts, whose absolute competence includes, among others, family law (al-ahwal al-syakhsiyah), the peace effort in divorce cases is a very noble business. It has many rewards, so efforts to reconcile household disputes must receive close attention. More seriously and deeply, regarding this situation, M. Yahya Harahap said, "Without reducing the meaning of the nobility of peace in all areas of dispute, the meaning of peace in divorce disputes has its noble value. By achieving peace between husband and wife in divorce

${ }^{18}$ Interview with Syafrudin Mohammad, Hasnia H.D., and Burhanudin Mokodompit., on 22 ${ }^{\text {nd }}$ of March 2021.

19 'Panitera Muda Hukum PA' Gorontalo, Loc.Cit. 
disputes, it is not only the integrity of the marital bond that can be saved. At the same time, the continuation of normal care and development of children can be saved. Harmony between the families of both parties can continue ${ }^{20}$.

Furthermore, Yahya Harahap said that the concord is related to family harmony, but joint property in marriage can sustainably support household life. Husband and wife can avoid social interaction disorders. Children's mental and psychological growth is protected from feelings of isolation and inferiority in social life. Considering all of this, efforts to reconcile divorce disputes are commendable and more important, take precedence over efforts to reconcile disputes in other fields. For the conciliation function to be carried out more effectively, the judge should find the factors behind the dispute as much as possible. Especially for divorce disputes for reasons of disputes and quarrels, the will and discretion of the judges are highly demanded to find the background factors that are the seeds of the cause ${ }^{21}$.

According to Drs, from the description above, and based on the author's observations and interviews with the mediator judge at the Gorontalo Religious Court, Syafrudin Mohamad, $\mathrm{MH}^{22}$, some main factors determine the success or failure of mediation, namely 1) the mediator, 2) the third party 3) and coming from the mediation room. While Drs. Burhanudin Mokodompit added that apart from the three factors mentioned above, mediation was successful by adding 4) factors from advocates/lawyers ${ }^{23}$.

For clarity, several factors caused the success or failure of mediation efforts at the Gorontalo Religious Court like at the Gorontalo Religious Court, there are eight judges and including chairman-seven judges play roles as mediators, but there are only two judges who have mediation certificates, namely a judge named Dra. $\mathrm{Hj}$. Hasnia HD, MH and Drs., Syafrudin Mohamad, MH.

According to Drs. Syafrudin Mohamad, MH, the mediator who does not master the case to help a mediation properly, it will further exacerbate their problems, the implementation of mediation to the parties, and disputing parties are not optimal. In addition to what often makes mediation fail, a judge brings himself to the mediation room and positions himself as a judge. He or she thinks of himself as a judge, then he will think that the right rules (often called 'black and white'). A mediator should put himself or herself into the mediation room as a mediator, not as a judge.

Furthermore, Drs. Syafrudin Mohamad, MH, stated that if you want the mediation to be successful, then a mediator must-have master required skills such as psychology, and sociology. Mediators' words play roles in changing something negative to positive. Mediator's words can soothe the hearts of the parties. In this case, the mediator's words can change the atmosphere-heated to cold and cool felt by the parties in the mediation ${ }^{24}$. According to a mediator judge, Dra. Hj. Hasnia HD, $\mathrm{MH}$, the cause of many unsuccessful mediations is because the mediator judges do not master the skills, do not master the understanding of psychological psychology from the mediating party. The mediator does not respect and does not look serious in hearing any complaints of the parties during the mediation. He further said that if you want the mediation to be successful, a mediator must master skills, psychology, and be willing to respect the complaints of the parties. A mediator must have special techniques in mediating, such as beginning with separate examinations,

\footnotetext{
${ }^{20}$ M. Yahya Harahap. Kedudukan, Kewenangan dan Acara Peradilan Agama, Jakarta. Pustaka Kartini, 1989, pp. 48-49.

${ }^{21}$ Ibid.

${ }^{22}$ Interview with a mediator judge, Syafrudin Mohamad, on 22 $2^{\text {nd }}$ of March 2021.

${ }^{23}$ Interview with a mediator judge, Burhanudin Mokodompit., on 22 ${ }^{\text {nd }}$ of March 2021.

${ }^{24}$ Interview with a mediator judge, Syafrudin Mohammad., on 22nd of March 2021.
} 
so that before they are met, the mediator has known the wishes of the parties and is offered about the wishes of one party to the other party so that they are aware and willing to accept to make peace with the agreements in the mediation room ${ }^{25}$.

Meanwhile, according to another judge mediator, Burhanudin Mokodompit, successful or unsuccessful mediation is determined by the mediator. A mediator must have tricks and must understand the case to be mediated, and the level of problems that occurs in the chaos in the household. A mediator must try to bring and lead the parties to the dispute, not to think about things that will lead them, not to think towards the source of division in the household, such as reviewing back to their good times in the past. A mediator should understand the situation. If a mediator does not understand the situation from the start, the mediation will not succeed ${ }^{26}$.

In practice, according to the author's observations, the function of judges as mediators is not well motivating and persisting. The lack of mediators' skills in trying to reconcile. The judge mediators have limited time due to the number of cases handled and must be completed every day. The mediator judge seems less optimal in mediating the litigants. Furthermore, there are mediator judges from outside the Gorontalo who do not master the local language and traditions of the Gorontalo community. Their interaction and communication with the parties to the dispute are less effective, miss-communication, and less understanding. Moreover, there are still litigants who do not master the Indonesian language.

According to a mediator Judge An. Dra. Hj. Hasnia HD, MH, the factors of the litigating parties will determine the success or failure of mediation because the good faith and willingness of the litigants will determine the success of the mediation. The litigants who have come to court have conducted deliberation and negotiations with the extended families of both parties. However, because they have not found a final point for their successful mediation through family deliberation, the parties come to court to register their cases and resolve domestic disputes. Above all, some parties are so disappointed, even worse, and their determination to divorce is very strong, the condition of their household is on the verge of collapse, so they will not be present in the mediation process, not even present at the trial so that the case is decided by 'verstek'27.

The second factor that caused the mediation to be unsuccessful, according to a mediator judge Drs. Syafrudin Mohamad, MH, is the disputing party who insists on getting a divorce. The disputing parties have been reconciled and discussed in their respective families but it failed. When they came to the Gorontalo Religious Court, their problems escalated and were determined to get a divorce so that there was no longer any will from the parties to get back together. Meanwhile, suppose the mediation is successful also from the parties' factors where the willingness of both parties wants to unite. In that case, the mediator must unite the wishes of both parties and be accepted by each party ${ }^{28}$.

Meanwhile, according to Drs. Burhanudin Mokodompit, the seriousness factor of the litigants greatly determines the success or failure of mediation, for example in a divorce case where there is a claim for compensation from the opposing party. The success rate is usually higher because many agreements are reached if there is a

\footnotetext{
25Interview with a mediator judge, and Hasnia H.D., on 22 ${ }^{\text {nd }}$ of March 2021.

${ }^{26}$ Interview with a mediator judge, Burhanudin Mokodompit, on 22 ${ }^{\text {nd }}$ of March 2021.

${ }^{27}$ Hasnia H.D., Loc.Cit.

${ }^{28}$ Syafrudin Mohammad., Loc.Cit.
} 
compensation claim, but it depends on the tricks used by the mediator. If the main problem is not successful, the compensation claim will be reached an agreement. However, the compensation claim agreement is not considered successful because it stands alone and is separate from the main claim ${ }^{29}$.

The parties usually come with their advocates/lawyers, and they usually do not participate in the mediation process held in religious courts. Everything related to dispute resolution both at the time of registration of the lawsuit and in terms of mediation settlement is completely handled by the advocate. However, supposed to be the client has determined to separate. In that case, the advocate will follow the client's wishes by saying that the client has determined to divorce his husband/ his wife so that mediation efforts carried out in court seem only as a formality to fulfill the rules of procedural law, even though if the lawyer wants to try to reconcile the parties, there will be a reconciliation through mediation both outside the court and in court because the court considers advocates/lawyers to be superior, and understand and clients.

According to Drs. Burhanudin Mokodompit, the factors of advocates/lawyers regarding the success or failure of this mediation that if the party uses a third party, in this case, is an advocate/lawyer as a facilitator who can bridge the success of mediation, but the failure of mediation can also be caused by the advocate/lawyer himself because of several cases he has experienced the failure of mediation is caused by lawyers/advocates themselves where when the Plaintiffs want to reconcile. However, their lawyers do not want them to make peace because it is related to the contract costs initially discussed with the Plaintiffs/applicants but will not be resolved if they have reconciled.

Meanwhile, according to Syafrudin Mohammad, lawyers are part of the party, some lawyers have good intentions to improve the household of their clients with the consideration that if the contract agreement has been paid in full, the lawyer will think that instead of continuing trials, he will try to be at peace with the mediation process, the pay is the same. However, some lawyers do the opposite, and therefore, in every mediation, the principles are prioritized ${ }^{30}$.

According to Drs. Syafrudin Mohamad, MH., 31 the mediation space factor also greatly determines the success or failure of mediation. If the mediation space is not representative, it will make the atmosphere even worse during mediation. The problems that arise in the mediation room, is often found, such as good air circulation, the room smells good, the room is air-conditioned and cold, and supported by adequate facilities such as a large table, soft chair, drinking water, the walls of the room which are fitted with wallpaper and TV media and pictures or writings arouse feelings such that could tell the consequences of divorce on their children so that the intention of both parties to the divorce will fade. The Plaintiff/applicant will withdraw his lawsuit.

\section{Closing}

The mediation has been implemented at the Gorontalo Religious Court as regulated by Perma No. 1/2016. However, the description of the unsuccessful implementation of this mediation can occur because the parties to the litigation have been preceded by lengthy negotiations between the families of both parties. Nevertheless, they did not reach a good agreement. The parties preferred litigation through the courts rather than resolving their cases through a mediator. The high failure of cases mediated at the Gorontalo Religious Court could occur because the

\footnotetext{
${ }^{29}$ Burhanudin Mokodompit., Loc.Cit.

${ }^{30}$ Ibid.

${ }^{31}$ Ibid.
} 
Defendant/Respondent parties were not present at the first trial, especially in divorce cases. The judge's decision was a 'verstek' decision. The success and failure factors of mediation can be caused by 4 (four) factors, namely the litigation party factor, the mediator factor, the advocate or lawyer factor, and the representative mediation room factor.

\section{BIBLIOGRAPHY}

Abbas, Syahrizal, Mediasi: Dalam Perspektif Hukum Syariah, Hukum Adat dan Hukum Nasional, Ed. I, Cet. I, Jakarta, Kencana, 2009.

Ali, M, Hatta, Peradilan Sederhana, Cepat dan Biaya Ringan Menuju Keadilan Restoratif, Edisi I, Cet. I, Bandung, Alumni, 2012.

Bik, A, Ibrahim, \& Wasil'Alauddin, A, Ibrahim., Ahkam, A, al-Syakhsiyah fi Syari'at al-Islam wa al-Qanun, Beirut, Dar Fikr al-'Araby, 1997.

Gunawan, E \& Hasan, F, Divorce Lawsuit Due to Polygamy in the Manado Religious Court, Al-Mizan, 13(2) (2017), 272-293.

Harahap, M, Y, Kedudukan, Kewenangan dan Acara Peradilan Agama, Jakarta. Pustaka Kartini, 1989.

Hasan, F; Yusuf, N; \& Luntajo, M. M. R., The Adjudication of Marriage Disputes through Mediation at the Manado Religious Court. INNOVATIO: Journal for Religious Innovation Studies, 20(2) (2020), 97-110.

Hoballah, M, "Marriage, Divorce and Inheritance in Islamic law" in Hisham, M, Ramadhan., (ed), Understanding Islamic Law from Classical to Contemporary, Newyork, Altamira Press, 2006.

Manan, B, “Sambutan pada Temu Karya Tentang Mediasi”, dalam buku Mediasi dan Perdamaian; Jakarta, Mahkamah Agung RI, 2004.

Nur, A., \& Fakhur, A, Hukum Acara Elektronik di Pengadilan Agama, Ed. I, Sidoarjo, Nizamia Learning Center, 2019.

Peraturan Mahkamah Agung RI Nomor 1 Tahun 2016 tentang Prosedur Mediasi di Pengadilan. 
Yasin, Faradila Hasan \& Fikri Amiruddin

Suadi, A, Pembaruan Hukum Acara Perdata di Indonesia: Menakar Beracara di Pengadilan Agama Secara Elektronik, Cet. I, Jakarta, Kencana, 2019.

Subekti, Arbitrase Perdagangan, Bandung, Bina Cipta, 1992.

Umam, Khotibul, Penyelesaian Sengketa Di Luar Pengadilan, Yogyakarta, Pustaka Yustisia, 2010.

Usman, Rachmadi, Pilihan Penyelesaian Sengketa Diluar Pengadilan, Bandung, Citra Aditya Bakti, 2003. 